\title{
Молекулярные маркеры в селекции лука репчатого
}

\section{Р.Р. Алижанова, С.Г. Монахос, Г.Ф. Монахос}

Исследования проведены в 2016-2018 годах в лаборатории генетики, селекции и биотехнологии овощных культур РГАУ-МСХА им. К.А. Тимирязева. Целью исследования являлась оценка эффективности известных молекулярных маркеров различных типов цитоплазмы CMS-S, CMS-T и N, гена закрепителя стерильности и восстановителя фертильности и гена, контролирующего устойчивость к пероноспорозу. Рекомендованные в научной литературе молекулярные маркеры orfA501 и 5» cob позволяют дифференцировать растения лука репчатого по трем типам цитоплазмы - CMS-S, CMS-T и N-цитоплазма. В нашем исследовании с использованием этих двух маркерных систем установлены типы цитоплазмы всех проанализированных растений с мужской стерильностью. У шести образцов выявлена CMS-S цитоплазма, у четырех образцов CMS-T и два образца обладали нормальной (N) цитоплазмой. Для создания линий закрепителей стерильности необходимо использование образцов с N-цитоплазмой, так как они должны обладать генотипом Nmsms. При классическом способе используют анализирующие скрещивания, где в качестве тестера берут стерильные растения с генотипом Smsms или Tmsms. И по потомству полученных $F_{1}$ гибридов судят о генотипе опылителя. Это требует как минимум 4 года работы. С помощью маркера Jnurf 13 проводят генотипирование на аллельное состояние локуса закрепления стерильности (msms) у растений с N-цитоплазмой, что сокращает процесс создания закрепителей стерильности в 4 раза. Доказано, что полная устойчивость Allium roylei к пероноспорозу контролируется одним доминантным геном Pd1. Маркер DMR1 выявляет наличие гена устойчивости Pd1 к ложной мучнистой росе. ПЦР-анализ с маркером DMR1 показал, что у устойчивого гибрида $\mathrm{F}_{1}$ Santero ген устойчивости находится в гетерозиготном состоянии, у восприимчивых сортов Денсити и Кенди - в рецессивной гомозиготы. B потомствах растений Sx (SxДенс) и Sx (SxКенди) наблюдали расщепление на устойчивые и восприимчивые, а среди устойчивых выявлены гомо- и гетерозиготные по гену Pd1.

Ключевые слова: лук репчатый, ядерно-цитоплазматическая мужская стерильность, молекулярно-генетическое маркирование, ядерный ген, пероноспороз, ген устойчивости Pd1.

Л ук сегодня одна из важнейших овощных культур во всем мире. В РФ площадь под луком в товарном производстве в 2017 году составила 25,3 тыс. га, а валовой сбор 1134,8 тыс. т при урожайности 44,8 т/га. За период с 2001 года урожайность выросла в 6,2 раза. Это связано с использованием современных технологий, в основе которых лежит переход от сортов к $\mathrm{F}_{1}$ гибридам. Работа по созданию современных гибридов проводится с использованием линий, обладающих ядерно-цитоплазматической мужской стерильностью (ЯЦМС), необходимой для гибридного семеноводства лука.

Мужскую стерильность классифицируют на два типа: CMS-S Clark, Jones (1943), CMS-T Beringer (1965) [1, 2].
Сначала в 1925 году стерильное растение с CMS-S цитоплазмой было выявлено у сорта Italian Red [3], у которого она контролировалась взаимодействием, вызывающей стерильность цитоплазмы и ядерного гена восстановителя $\mathrm{Ms} / \mathrm{ms}$ в рецессивном состоянии (msms). Позже в 1960 году во французском сорте Jaune Paillede Vertus выявили CMS-T цитоплазму [2]. Фертильность растений с такой цитоплазмой восстанавливается двумя независимыми системами восстановителей. Первая состоит из одного локуса А с двумя аллелями, а вторая из двух комплементарно действующих локусов В и С. Доминантные аллели во всех системах являются восстановителями фертильности, а рецессивные - закрепителями стерильности [4]. Фенотипически стерильные растения c S- и Т- цитоплазмой различить невозможно, что затрудняет их использование в селекции.

Для идентификации типа ЦМС у лука репчатого зарубежными исследователями разработана система молекулярных маркеров [5].

Sunggil Kim в 2013 году разработал молекулярные маркеры для определения гена закрепителя стерильности/восстановителя фертильности [6, 7]. Он обнаружил, что маркер Jnurf-13 сцепленный с локуcom Ms для системы CMS-S идеально маркировал этот же локус у системы CMS-T. Эти результаты исследования противоречат предыдущей модели восстановления фертильности в системе CMS-T.

Предложенная система маркеров позволяет существенно снизить число индивидуальных скрещиваний со стерильным тестером из тесткроссов и облегчить отбор желаемых растений с генотипом закрепителя стерильности Nmsms.

Цель нашего исследования: оценка эффективности известных молекулярных маркеров различных типов цитоплазмы CMS-S, CMS-T и N, гена закрепителя стерильности/восстановителя фертильности и гена, контролирующего устойчивость к пероноспорозу.

Условия, материалы и методы исследований. Исследования проведены в 2016-2018 годах в лаборатории генетики, селекции и биотехнологии овощных культур РГАУМСХА имени К.А. Тимирязева. В работе представлены результаты молекулярно-генетического анализа растений лука репчатого из коллекции ООО «Селекционная станция им. Н.Н.Тимофеева», а также современные $\mathrm{F}_{1}$ гибридов зарубежной селекции - Сантеро, Медуза, Роухай, Ятоба, Барита и др. Для анализа растений использовали маркеры, предложенные T. Engelke с соавторами (2002) для дифференциации типов цитоплазмы, S. Kim (2013) - на ген закрепитель стерильности, а также 
Таблица 1. Дифференциация (N) -, (T) -, и (S) -типов цитоплазм при сочетании маркеров 5" cob и orfA501

\begin{tabular}{|c|c|c|c|}
\hline \multirow{2}{*}{ Тип цитоплазмы } & \multicolumn{2}{|c|}{ 5»cob } & \multirow{2}{*}{$\begin{array}{l}\text { orfA501 } \\
473 \text { п.н. }\end{array}$} \\
\hline & 180 п.н. & 414 п.н. & \\
\hline$(\mathrm{N})$ & + & - & - \\
\hline$(\mathrm{T})$ & + & - & + \\
\hline (S) & $(+)$ & + & + \\
\hline
\end{tabular}

Таблица 2. Результаты молекулярно-генетического и фенотипического анализа растений коллекции лука репчатого, Москва, 2018 год

\begin{tabular}{|c|c|c|c|c|}
\hline \multirow{2}{*}{ Генотип } & \multirow{2}{*}{$\begin{array}{c}\text { Число } \\
\text { растений }\end{array}$} & \multicolumn{2}{|c|}{$\begin{array}{c}\text { Число растений по } \\
\text { фенотипу }\end{array}$} & \multirow{2}{*}{$\begin{array}{c}\text { Тип цитоплазмы } \\
\text { согласно } \\
\text { молекулярно- } \\
\text { генетическому } \\
\text { анализу }\end{array}$} \\
\hline & & стерильные & фертильные & \\
\hline Сантеро & 6 & 6 & & $\mathrm{~T}$ \\
\hline Ятоба & 6 & 4 & 2 & S \\
\hline Барита & 11 & 11 & & $\mathrm{~T}$ \\
\hline Роухай & 4 & 4 & & S \\
\hline ЛФК & 3 & 1 & 2 & S \\
\hline Брекстоун & 2 & 2 & & S \\
\hline Шлт & 5 & & 5 & $\mathrm{~N}$ \\
\hline МсБн & 3 & 3 & & $\mathrm{~T}$ \\
\hline Медуза & 2 & 2 & & $\mathrm{~S}$ \\
\hline Олоросо & 3 & 3 & & S \\
\hline [Бн1-12хВал 1-8] 1 & 7 & & 7 & $\mathrm{~N}$ \\
\hline Снайпер & 2 & & 2 & S \\
\hline Салатный & 5 & 5 & & $\mathrm{~T}$ \\
\hline
\end{tabular}

маркеры DMR на ген устойчивости к пероноспорозу Pd1.

Лук репчатый выращивали в условиях открытого грунта или пле-

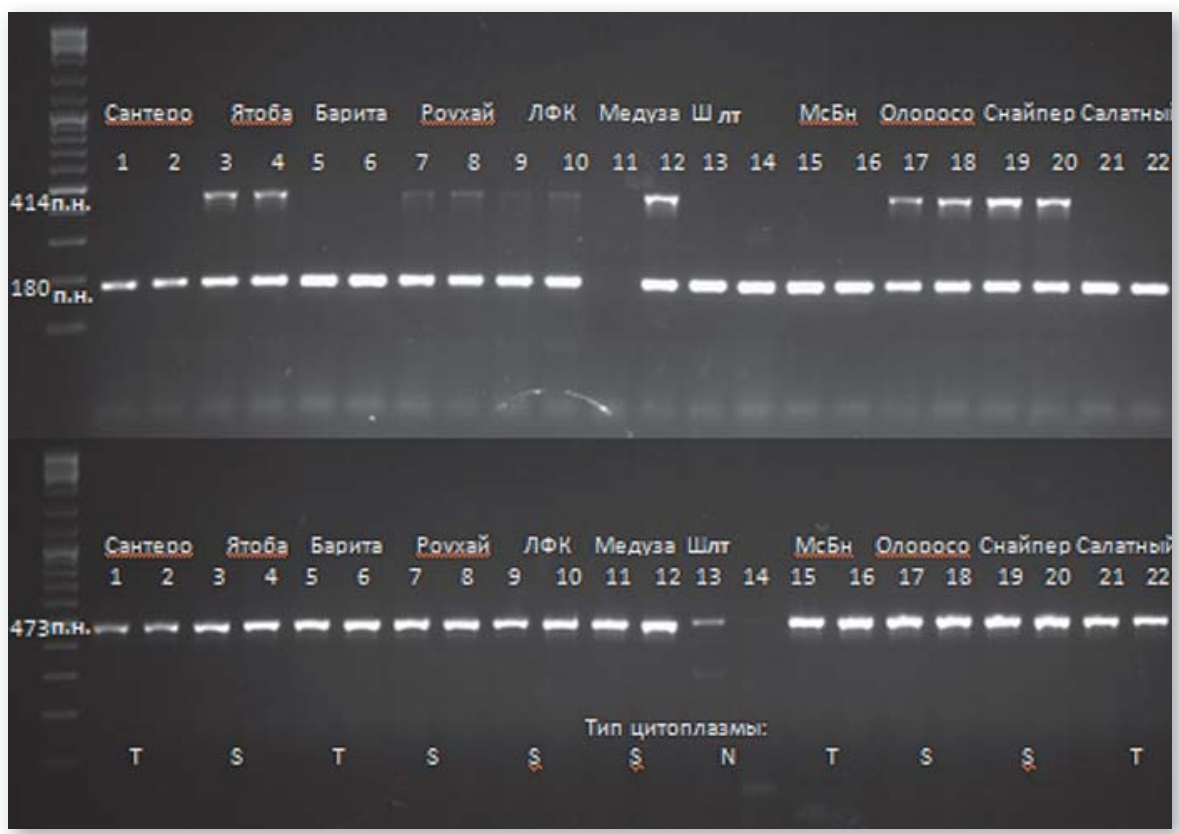

Рис. 1. Электрофореграмма продуктов амплификации и дифференциация образцов по типу цитоплазмы (CMS-S, CMS-T и N) с использованием маркеров orfA501 и 5'cob при пониженной температуре, затем растения высаживали в теплицу, где они стрелковались и цвели. Из отрастающих молодых листьев выделяли ДНК согласно СТАВ-методу Murray\&Thompson [8]. ПЦР проводили по методикам, описанным в публикациях авторами молекулярных маркеров.

МаркероrfA501Т-цитоплазмы (ожидаемый фрагмент 473 п.н.) амплифицировали с праймерами 5'-ATGGCTCGCCTTGAAAGAGAGC-3» и 5'-CCAAGCATTTGGCGCTGAC3'при температуре отжига $60{ }^{\circ} \mathrm{C}$. Маркер5'cobS-цитоплазмы амплифицировали с использованием прямого праймера 5'-GTCCAGT TCCTATAGAACCTATCACT-3», (ожидаемый фрагмент 414 п.н.), маркер нормальнойN-цитоплазма, характеризующийся длиной фрагмента180 п.н., - с прямым праймером5'TCTAGATGTCGCATCAGTGGAATCC-3» и использованием общего обратного праймера5'CTTTTCTATGGTGACAACTCCTCTT 3'при температуре отжига $53^{\circ} \mathrm{C}$.

Для определения гена закрепителя стерильности нами был выбран маркер Jnurf-13 [7]. Праймеры для Jnurf-13 это 5 ' -TTGCCAAAGGTTGCAATACA-3 » и 5'-TGCAAGCTTGGAACTTACG-3», температура отжига $57{ }^{\circ} \mathrm{C}$, ожидаемый для доминантного аллеля Ms фрагмент - 241 п.н., рецессивного ms- 229 п.н.

Продукты амплификации разделяли электрофорезом в 1,5\% агарозном геле, визуализировали в проходящем УФ свете при окрашивании красителем GelRed.

Результаты исследований. Engelke et al. (2003) предложили систему дифференциации (N) -, (T) -, и (S) -типов цитоплазм при сочетании маркеров 5» cob и orfA501.

По результатам ПЦР-анализа нормальная цитоплазма выявилась у растений образцов Шлт и [Бн112хВал 1-8] 1. У них присутствовал только один целевой фрагмент длиной 180 п.н. (рис. 1). Наличие маркера S-типа цитоплазмы обнаружено у гибридов ЛФК, Ятоба, Роухай, Олоросо, Медуза, Снайпер. У перечисленных образцов выявлены все три фрагмента длиной 180 п.н., 414 п.н. и 473 п.н.

y $F_{1}$ гибридов Сантеро, Барита, МсБанко и Салатный анализ показал присутствие двух фрагментов длиной 180 п.н. и 473 п.н., что свидетельствует о наличии у них Т-цитоплазмы. 


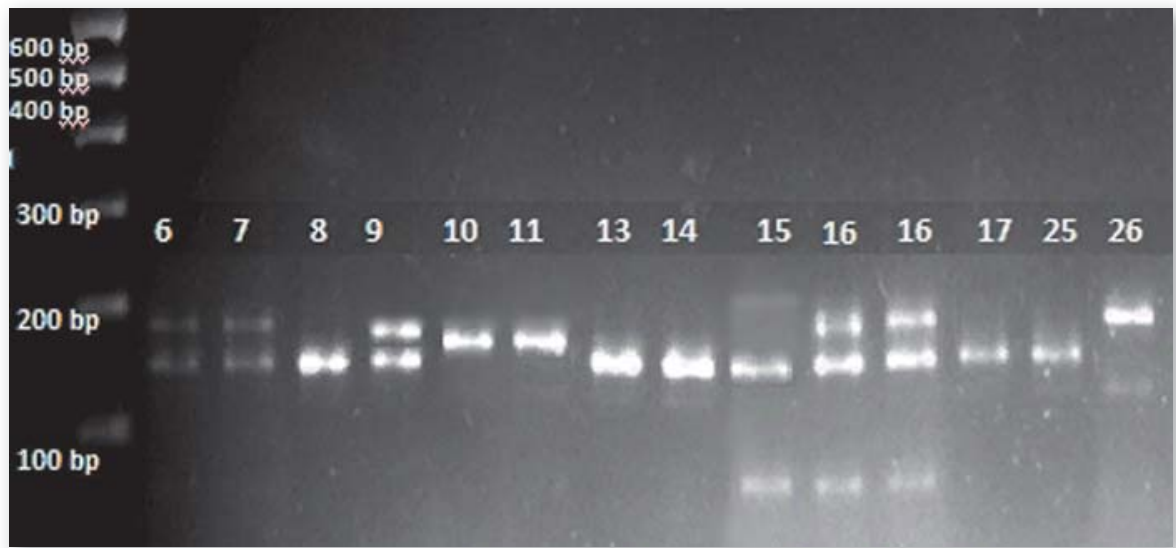

Рис. 2. Электрофореграмма продуктов амплификации и дифференциация растений потомства [Бн1-12хВал 1-8] 1 с использованием маркера Jnurf 13

Одновременное использование этих двух систем маркирования дифференцировало типы цитоплазм всех проанализированных образцов с мужской стерильностью. Вместе с тем в некоторых образцах со стерильной цитоплазмой наблюдалось расщепление по фенотипу на стерильные и фертильные, что связано с использованием различных по локусу $\mathrm{Ms} / \mathrm{ms}$ генотипов отцовских линий.

По результатам анализа был сделан вывод о пригодности данного метода для оценки растений лука репчатого, показана высокая эффективность двух систем маркирования orfA501 и 5» cob для выявления фактора стерильности в цитоплазме типа CMS-S, CMS-T и они могут быть использованы в селекции. Для создания линий закрепителей стерильности необходимо выявление образцов с $\mathrm{N}$-цитоплазмой, так как они должны обладать генотипом
Nmsms. Для выявления таких растений при классическом способе проводят анализирующие скрещивания, где в качестве тестера используют стерильные растения с генотипом Smsms или Tmsms. И по потомству полученных $F_{1}$ гибридов судят о генотипе опылителя. Если все потомство стерильное, то отцовские растения с нормальной цитоплазмой являются закрепителями стерильности с генотипом Nmsms. Это требует, как минимум, четыре года работы. При использовании маркеров orfA501 и 5» cob на тип цитоплазмы выявляют растения с N-цитоплазмой и у этих растений с помощью маркера Jnurf 13 проводят генотипирование на аллельное состояние локуса закрепления стерильности (msms), что сокращает процесс создания закрепителей стерильности в четыре раза.

В результате ПЦР-анализа по маркеру Jnurf 13 растений потомства [Бн1-12хВал 1-8] 1 с нормальной ци- топлазмой показано, что шесть растений под номерами 8, 13, 14, 15, 17,25 обладали генотипом закрепителя стерильности msms (рис. 2). Растения 6,7,9,16 - гетерозиготы, а 10,11,26-доминантные гомозиготы восстановители фертильности. Таким образом, по результатам анализа без использования трудоемких анализирующих скрещиваний, выделены и вовлечены в селекционный процесс растения с генотипом закрепителя стерильности.

Высокая вредоносность пероноспороза (возбудитель - оомицет Peronospora destructor) делает актуальным поиск источников и доноров устойчивости. Показано, что Allium roylei полностью устойчив к этому заболеванию, и устойчивость контролируется одним доминантным геном Pd1 [9]. В 2015 году корейскими учеными S.Kimet с сотрудниками были разработаны четыре молекулярных маркера сцепленных с геном устойчивости Pd1.В 2016 году мы провели анализ популяций лука репчатого, полученных гибридизацией восприимчивых линий и устойчивым к ложной мучнистой росе $\mathrm{F}_{1}$-гибридом Santeroc использованием трех молекулярных маркеров DMR1, DMR2 и DMR3 (Kim et al., 2016). Для дальнейших исследований был отобран DMR1-маркер как наиболее тесно сцепленный с Pd1геном устойчивости к пероноспорозу. Маркер доминантного Pdаллеля устойчивости при амплификации с парой праймеров DMR1R5' -TTCGTAGCAGCATCAAGGTG-3» $\begin{array}{llllllllllll} & n & D & M & R & 1 & - & F & -\end{array}$ 5'-TGAGGCTCAAGTTGACATG-3» дает фрагмент размером 505 п.н., а ре-

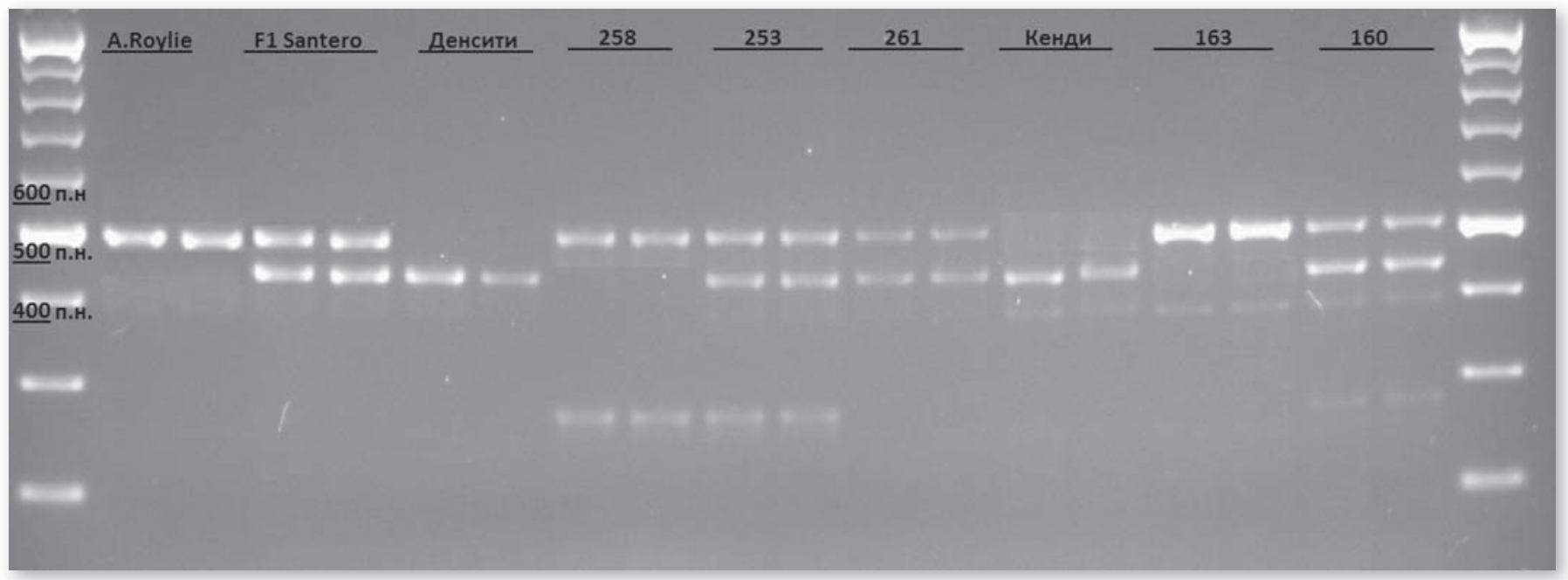

Рис. 3. Электрофореграмма продуктов амплификации и дифференциация образцов лука репчатого по наличию/отсутствию гена устойчивости Pd1 с использованием маркера DMR1. Каждый образец представлен двумя дорожками 
цессивному аллелю pd соответствует фрагмент размером 438 п.н.Условия ПЦР были следующими: $95^{\circ} \mathrm{C}-4$ мин; 10 циклов денатурация при $95^{\circ} \mathrm{C}-30$ сек; отжиг при $65^{\circ}$ Ссуменьшением в каждом цикле на $0,8^{\circ} \mathrm{C}-30$ сек, синтез при $72{ }^{\circ} \mathrm{C}-1$ мин; 35 циклов $95^{\circ} \mathrm{C}-$ 30 сек; $57{ }^{\circ} \mathrm{C}-30$ сек; $72{ }^{\circ} \mathrm{C}-1$ мин; 10 мин - $72^{\circ} \mathrm{C}$. ПЦР-продукты разделяли в 1,5\% агарозном геле и визуализировали при окрашивании GelRed в проходящем УФ-излучении.

ПЦР с маркером DMR1 показал, что у гибрида $F_{1}$ Santero ген устойчивости находится в гетерозиготном состоянии, у сортов Денсити и Кенди присутствует фрагмент длиной 438 п.н., что соответствует рецессивному аллелю в гомозиготном состоянии В потомствах растений Sx (SхДенс) $(258,253,261)$ и Sx (SхКенди) (163, 160) наблюдалось расщепление на устойчивые и восприимчивые (рис. 3). Среди устойчивых растений в потомстве Sx (SхДенс) присутствовали растения (253 и 260) с двумя фрагментами 505 п.н. и 437 п.н., что свидетельствует об их гетерозиготности, и растение № 258 с фрагментом длиной 505 п.н.- гомозиготности по доминантному аллелю. B потомстве Sx (SxКенди) выявлено, что растение № 163 является доминантной гомозиготой, а растение № 160-гетерозиготой.

Таким образом, показано, что ген устойчивости Pd1 стабильно передается гибридному потомству, а маркер DMR1 четко выявляет его гомоили гетерозиготное состояние и может быть эффективно использован в селекции для отбора устойчивых к пероноспорозу растений.

\section{Библиографический список}

1.Clarke, A.E., H.A. Jones, and T.M. Little. Inheritance of bulb color in onion. Genetics. 1944. No 29: Pp. 569-575.

2.Berninger $\mathrm{E}$. Contribution a l'etude de la sterilite male de l'oignon (Allium cepa L.). Ann. Amelior. Plant (Paris). 1965. No 23. Pp. 183-199.

3.Jones H., S. Emsweller. A male sterile onion. Proc. Amer. Soc. Hort. Sci. 1936. No 34. Pp. 582-585.

4.Schweisguth B.. Etude d'un nouveau type destérilité mâle chez l'oignon, Allium cepa L. Ann. Amelior. Plant. 1973. No 23. Pp. 221-233.

5.Engelke T., Terefe D., Tatlioglu T. A PCR-based marker system monitoring CMS- (S), CMS- (T) and (N) -cytoplasm in the onion (Allium cepa L.). Theor. Appl. Genet. 2003. No 107 Pp. 162-167.

6.Kim S. A codominant molecular marker in linkage disequilibrium with a restorer-of-fertility gene (Ms) and its application in reevaluation of inheritance of fertility restoration in onions. Mol Breeding. 2014. No 34 Pp.769-778.

7.Seongjun Kim, Cheol-Woo Kim, M Choi, Sunggil Kim. Development of a simple PCR marker tagging the Allium roylei fragment harboring resistance to downy mildew (Peronospora destructor) in onion (Allium cepa L.) // Euphytica. 2015. DOI: 10.1007/s10681-015-1601-2.

8.Murray M.G., Thompson W.F. Rapid isolation of highmolecular-weight plant DNA // Nucleic Acids Res. 1980.

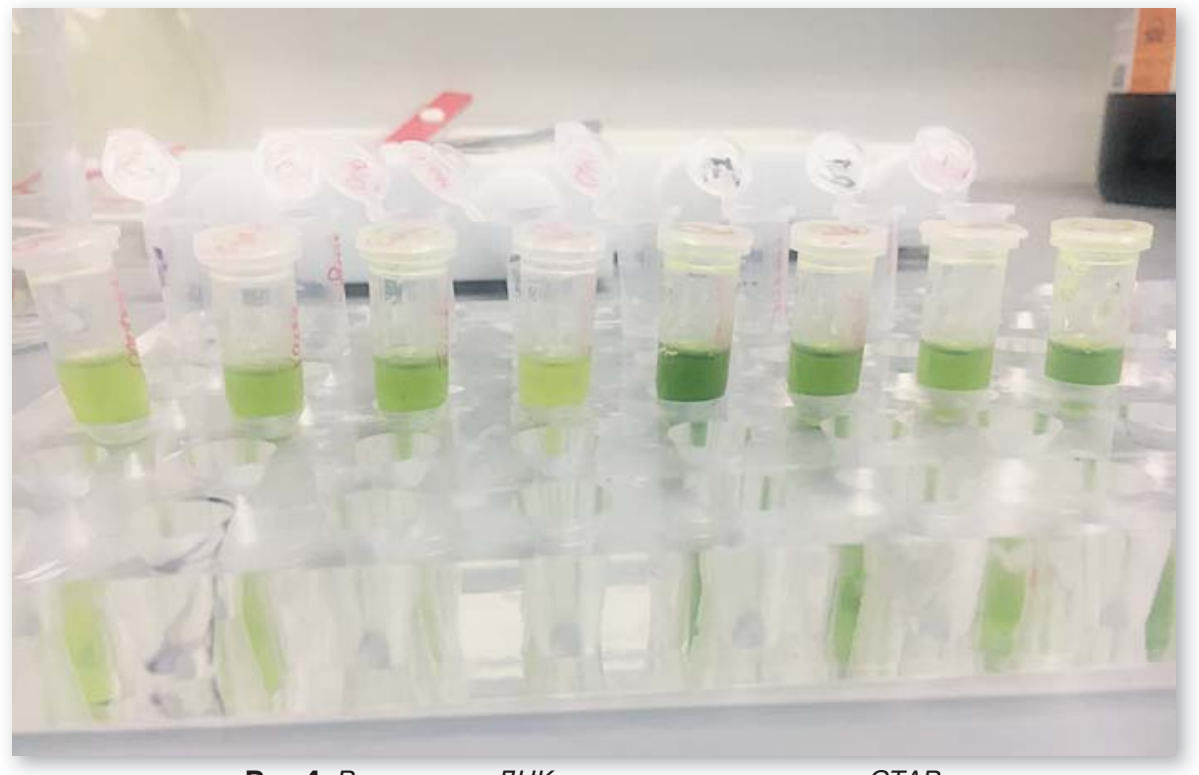

Рис 4. Выделение ДНК стандартным методом СТАВ

No 8. Pp. 4321-4325

9. Kofoet A., Zinkernagel V. (1990) Resistance to downy mildew (Peronospora destructor (Berk.) Casp.) in Allium species. // J. Plant Dis Prot. 97 (1) Pp. 13-23.

\section{Об авторах}

Алижанова Рада Расимовна, аспирант кафедры ботаники, селекции и семеноводства садовых растений РГАУ-МСХА имени К.А. Тимирязева. Тел. +7 (915) 425-63-29. E-mail: rada.aliz@mail.ru.

Монахос Сократ Григорьевич, заведующий кафедрой ботаники, селекции и семеноводства садовых растений, РГАУ - МСХА имени К.А.Тимирязева, доктор с. - х. наук, тел. +7 (499) 976-41-71. E-mail: s.monakhos@rgau-msha.ru.

Монахос Григорий Федорович, генеральный директор ООО

«Селекционная станция имени Н.Н. Тимофеева», канд. с. - х. наук; тел. +7 (499) 977-11-74.E-mail: breedst@ mail.ru.

Molecular markers in onion breeding

R.R. Alizhanova, postgraduate,

Department Botany, Plant Breeding and Seed Technology, RSAU-MTAA; tel. 8-915425-63-29. E-mail: rada.aliz@mail.ru.

S.G. Monakhos, Head of the Department

Botany, Plant Breeding and Seed

Technology,

RSAU-MTAA, Dr. Sci. in Agricultural sciences; tel. +7 (499) 976-41-71. E-mail:

s.monakhos@rgau-msha.ru.

G.F. Monakhos, PhD, General Director, Limited company «Breeding station after N.N. Timofeev»; tel. +7 (499) 977-11-74. E-mail: breedst@mail.ru.
Summary. The studies were conducted in 2016-2018 in the laboratory of genetics, breeding and biotechnology of vegetable crops of the RSAU - MTAA. The aim of the research is to assess the efficiency of known molecular markers orfA501 и 5" cob to genotype a type of onion (Allium cepa L.) male sterility inducing cytoplasm's, CMS- (S) and CMS- ( $T$ ) and normal $(N)$ cytoplasm, to genotype restorer fertility and maintainer sterility alleles $\mathrm{Ms} / \mathrm{ms}$ of a nuclear gene, marker of onion downy mildew resistance gene. The use of these two marker systems (orfA501 и 5» cob) confirmed the type of cytoplasm of all screened male sterility onion plants. Six onion accessions had CMS-S type of cytoplasm, four accessions - CMS-T and two accessions had normal N-cytoplasm. The efficiency of recommended DNA-marker Jnur $\mathrm{F}_{1} 3$ to genotype restorer fertility (Ms) allele and maintainer sterility (ms) allele of a nuclear gene was confirmed using a set of different onion accessions. The use of molecular marker Jnurf 13 helps to genotype the onion plant in relation to allelic state of the sterility maintainer allele ( $\mathrm{ms}$ ) in plants with $\mathrm{N}$-cytoplasm and shortens the process of developing sterility maintainer lines. Allium roylei is completely resistant to downy mildew which is controlled by a single dominant Pd1 gene. Marker DMR1 of onion downy mildew resistance gene was studied using an accessions of Timofeev's plant breeding station (RSAU - MTAA) involved in a breeding programs and commercial cultivars of foreign companies.

Keywords: onion (Allium cepa L.), cytoplasmic male sterility, DNA markers, downy mildew, resistance gene, restorer fertility, maintainer sterility 